\title{
Dynamics Of The Relationship Between Bank Loans And Stock Prices In Saudi Arabia
}

Saud Almutair, Al-Imam Muhammad Ibn Saud Islamic University, Saudi Arabia

\begin{abstract}
The objective of this study is to find the dynamics of the relationship between bank loans and stock prices in Saudi Arabia using quarterly data for the period 1998 to 2013. The estimation methodology consists of a cointegration test, an error correction model estimation, and VAR Granger Causality. The study confirms the long-run relationship between credit card loans (CCLOAN) and Saudi's stock market index (SSPI). A positive relationship between SSPI and bank loans, supporting the economic theory that as stock prices rise, the supply and demand for bank loans increase was found. This positive relationship between SSPI and bank loans is true for all types of bank loans except CCLOAN. The negative relationship between CCLOAN and SSPI can be justified because CCLOAN is affected mainly by the consumption decision, which depends on the wealth effect. The study confirms that the total bank loans (TOTALL) react positively to an increase in stock prices in Saudi Arabia, and not the other way around, supporting the efficiency hypothesis of the stock market of Saudi Arabia. Therefore, the study tends to conclude that TOTALL plays no significant role in transmitting stock market shocks to the real sector. An important implication obtained from this study is that the health of the banking sector depends crucially on stock market stability. Policies to stimulate bank loans in an attempt to boost stock market activities may be futile in Saudi Arabia.
\end{abstract}

Keywords: Stock Market; Saudi's Bank Loans; Error Correction Model; VAR; VECM; Saudi Arabia; Bank Loans; Stock Prices; Efficient Market; Cointegration

\section{INTRODUCTION}

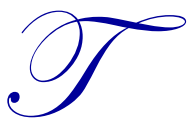

he link between stock market development and financial intermediaries has been an increasingly significant determinant of economic development. Stock market development can influence economic activity through four mechanisms, namely, investment spending (Tobin's q theory), household liquidity effects, household wealth effects, and firm balance-sheet effects. Many researchers have found that the economic growth and development of a country depend on investments, which require long-term funding. Therefore, the stock market plays a fundamental role in the economic growth and development of a country (Aydemir and Demirhan, 2009). It also helps in distributing the wealth of a nation by enabling wider ownership of company stocks. Investors can buy the shares of publicly listed companies, thus enabling them to become business owners and earn a share of business profits based on their invested capital. Thus, healthy economic growth is always accompanied by a healthy financial market transmitting its influence to the real sectors. The importance of "good" performance of the stock market is obvious. History has shown that a downturn in stock prices can lead to major disturbances in the lives of many. Further, the strength of a stock market can have a major effect on the economy by its influence on real activities such as consumption, investments, etc.

The performance of the stock market depends on many factors and is highly susceptible to the economic and political conditions of countries. If the overall economic condition of a country is good, the stock market usually has better returns, and vice versa. Nowadays, the emergence of financial intermediaries increasingly plays an 
important role in providing financial assistance to the expansion of corporations. However, the growing importance given to developing the stock market and financial intermediaries has raised many critical questions: do stock prices predict the future lending activities of banks? Do bank loans play an important role in transmitting financial shocks to the real sectors, and if so, how? (Karim, Lih, and Karim, 2012).

Economists believe that stock prices are a good predictor of future economic development. Thus, stock market development plays an important role in predicting future economic growth (Levine and Zervos, 1998). In addition, Demirguc-Kunt and Levine (1996) found that most of the stock market indicators are highly correlated with banking sector developments. Therefore, most of the well-developed stock markets tend to have a welldeveloped banking sector. Furthermore, Demirguc-Kunt and Maksimovic (1996) show that firms in countries with banks and equity markets that function relatively better tend to grow faster than predicted by individual firm characteristics. Thus, stock prices should reflect the various macroeconomic variables indicating the current economic development. If stock prices reflect all the macroeconomic variables, it would be a good tool to predict the future bank lending activities, because the stock market indicators are the macroeconomic variables that determine bank lending (Yartey, 2008). Monetary policy is one of the most effective tools that a central bank has at its disposal. Central banks frequently use monetary policy to induce a desired level of change in real activities. These frequent changes in monetary policy are believed to have a significant effect on banks' loans that may in turn have an effect on the stock market. For policy makers, it is important to first understand how an economic transformation affects the nature of the mechanism of monetary transmission and then evaluate the relative potency of the transmission channels (Ooi, 2008). The stock market and banking sector developments may facilitate policies that improve the stability of the banking industry and enhance the effectiveness of the monetary system as a whole (Omar et al., 2006). Notably, to the extent that bank loans are collateralized by stocks such as real property and shares, a fall in share prices can expose banks to default risks that in turn may adversely affect the loan supply behavior of banks (Kim and Moreno, 1994). Banks face various risks in their role as financial intermediaries, such as interest rate risks, exchange rate risks, default risks, and asset price risks.

While economic theory confirms a positive relationship between bank loans and the stock price index, there are different views on the causality issue. This study has the following aims:

1. Find whether there exists cointegration between the various types of bank loans and the stock price index in Saudi Arabia,

2. Discover the nature of the relationship between bank loans and the stock price index in Saudi Arabia, and

3. Explore the direction of causality between stock prices and bank lending activities in Saudi Arabia.

A deeper understanding of the banking sector's vulnerability and the mechanism of stock prices in the real market was also provided. Our causality results provide an important implication for the market efficiency hypothesis (MEH). If the predictability of Saudi Arabia's stock prices can be enhanced considerably by using the information on bank loans, then it means that Saudi Arabia's stock market is not efficient, and vice versa. This study proceeds as follows: section II presents our literature review; section III reviews the theoretical model; section IV discusses the data and empirical methodology; section V derives the empirical results; and section VI concludes the study.

\section{LITERATURE REVIEW}

Few studies have tried to find the relationship between bank loans and stock prices and to explore the direction of causality. As far as the author's knowledge goes, three studies have examined the interaction between bank loans and stock prices in Japan and Malaysia.

Kim and Moreno (1994) try to shed light on whether stock price movements have contributed to fluctuations in bank lending in Japan by examining the historical relationship between stock prices and bank lending. In particular, they evaluate the issue using monthly data from January 1970 to May 1993 by applying a vector autoregressive framework. They come up with the following conclusions: first, the response of Japanese bank lending to an increase in stock prices is positive in the two sample periods (1970.1-1983.12, and 1984.1-1993.5). This result is intuitive and consistent with the effect of stock prices on the demand and supply of loans. Second, 
there is a change in the historical relationship between stock prices and bank lending. This relationship was weak until the mid-1980s but became quite significant subsequently. Third, the fluctuations in the Nikkei stock prices during that period seem to have contributed significantly to the fluctuations in bank lending in Japan. In particular, the Nikkei stock prices appear to have played an important role in accounting for the recent sluggish growth in lending in Japan. In short, since the late 1980s, stock price fluctuations appear to have contributed to fluctuations in bank lending in Japan.

Chen (2001) studies the price fluctuations of two major assets in Taiwan observed from 1973 to 1992, real estate and stocks. While equity prices are found to Granger-cause real estate prices, bank loans are found to be much more significant than interest rates for predicting the price movements of both assets. This suggests that the asset price fluctuations in Taiwan support the theory that emphasizes the importance of balance sheet position and collateral value for credit-constrained firms. A credit expansion is then accompanied by a rapid rise in prices of assets such as real estate and stocks. At a certain point, the asset markets would collapse and their prices plunge from a change in the regulatory or economic environment. The collapse of asset prices and exposure of banks to equity and real estate markets therefore lead to defaults of debtors, banking crises, and persistent economic downturns. This could be accompanied by an exchange rate crisis.

Ibrahim (2006) estimates stock prices and bank loans in Malaysia. Using vector autoregressive models (VAR) to assess the dynamic interaction between bank loans and stock prices, he examines whether bank loans help in transmitting financial shocks to the real sector. Moreover, the causal relationship between stock prices and bank lending has an important role in providing a deeper understanding of the vulnerability of banking and the mechanism of stock prices in the real market. He finds evidence that bank loans react positively to an increase in stock prices, but there seems to be no influence from bank loans to stock prices. Similarly, bank loans seem to accommodate an expansion in real output, but again there seems to be no influence from bank loans to real economic activity. In addition, the exchange rate seems to affect banks' lending activities through its effects on real output and stock prices. From these dynamic responses, Ibrahim (2006) tends to conclude that bank loans have no significant role in transmitting stock market shocks to the real sector. An important implication from the analysis of this papers is that the health of the banking sector depends crucially on the stability of the stock market and real output. Thus, policies to stimulate bank loans in an attempt to boost stock market activities as well as expand the real activities may be futile.

Karim, Lih, and Karim (2012) re-examine the interaction between bank loans and stock prices in Malaysia. They use Granger non-causality tests in both bivariate and multivariate frameworks with both monthly and quarterly data and examine the relationship between the two variables. Unlike previous studies, they find strong evidence of no causality between stock prices and bank loans in all models and samples. This finding has shown that stock prices and bank loans are independent. The predictability of stock prices does not increase much from the use of bank loan information, leading us to conclude that the Malaysian stock market is efficient.

\section{THEORETICAL MODEL}

The interaction between banks and the stock market cannot be ignored. A relatively high stock price index indicates future prosperity and acts as a good signal to banks to increase their loans. On the other hand, as banks increase their loans, some share of the loans may find its way to the stock market and result in still higher stock prices. The changes in stock prices may influence bank lending through two channels, demand and supply. First, through the demand channel, stock price fluctuations affect the demand for loans by signaling changes in future economic activity. For example, a decline in stock prices may reflect contractionary influences that lower the demand for loans, such as a decline in corporate capital spending triggered by a slump in final demand, poor corporate earnings, and excess capacity. As stock prices go up, the demand for loans may rise for at least two reasons:

1. A rise in stock prices attracts individuals and firms to invest more in the stock market: as the difference between the returns on stocks and cost of borrowing increases, investors can gain more profits.

2. A booming stock market means that companies can expect good future progress, which leads them to expand and go in for more financial borrowings. 
Second, through the supply channel, stock price fluctuations affect the supply of loans. As the price of stock goes up, the supply of loans may rise for at least two reasons:

1. Banks become more optimistic toward future prosperity and are encouraged to lend more.

2. The capital position of banks may be affected because banks can use their capital gains on stocks as cushion against adverse shocks to assets, and this may enhance the supply of loans.

In short, other things remaining equal, a positive relationship between stock prices and bank lending because the supply of bank loans reinforces the demand for loans can be expected.

While economic theory confirms the positive relationship between stock prices and bank loans, the causality is not well defined. As stock prices go up, the demand as well as supply of loans increases, indicating that causality runs from stock prices to quantity of loans. On the other hand, as banks offer more loans to firms and individuals, some loans may go to investment in the stock market, leading to a higher demand for stocks and driving stock prices up.

\section{DATA AND EMPIRICAL METHODOLOGY}

\section{Data}

The objective of this paper is to investigate the dynamics of the relationship between Saudi's stock price index (SSPI) and bank loans using quarterly data for the period 1998 to 2013. In this study, the variables are the SSPI and bank loans. The study uses different types of loans:

1. Credit cards loans (CCLOAN)

2. $\quad$ Consumer bank loans (CLOANS)

3. Total bank loans (TOTALL)

4. Other consumer bank loans (OLOAN). This can be computed by subtracting the real estate loans and car and equipment finance from CLOANS.

The data used for this study were obtained from the U.S. Federal Reserve Bank of Saint Louis and Saudi Arabia's Monetary Agency and Capital Market Authority as found in their various issues of annual reports and quarterly bulletins.

The estimation methodology of this paper consists of four steps: a unit root test, cointegration test, the error correction model estimation (VECM or VAR), and VAR Granger causality. 


\section{Decomposition Of Bank Loans}

Table 1 shows the decomposition of bank loans and the importance of each component as magnitude and ratio.

Table 1. Decomposition Of Bank Loans

\begin{tabular}{lccccccc}
\hline $\begin{array}{c}\text { End Of } \\
\text { Period }\end{array}$ & $\begin{array}{c}\text { Total Bank } \\
\text { Loans (Million) }\end{array}$ & $\begin{array}{c}\text { Consumer } \\
\text { Loans (Million) }\end{array}$ & $\begin{array}{c}\text { Total Credit } \\
\text { Card Loans** } \\
\text { (Million) }\end{array}$ & $\begin{array}{c}\text { Others Consumer } \\
\text { Loans** } \\
\text { (Million) }\end{array}$ & $\begin{array}{c}\text { Ratio Of Consumer } \\
\text { Loans To Total } \\
\text { Bank Loans \% }\end{array}$ & $\begin{array}{c}\text { Ratio Of Credit } \\
\text { Card Loans To } \\
\text { Consumer Loans \% }\end{array}$ & $\begin{array}{c}\text { Ratio Of Other } \\
\text { Loans To } \\
\text { Consumer Loans \% }\end{array}$ \\
\hline 1998 & 664044 & 9024.596 & 2143.404 & 5246.263 & 1.359 & 2.8577961 & 58.1329 \\
\hline 1999 & 649421 & 12292.21 & 2315.788 & 7710.974 & 1.8928 & 2.3550002 & 62.7306 \\
\hline 2000 & 668060 & 24755.71 & 2112.441 & 14312.37 & 3.7056 & 4.0675951 & 57.8144 \\
\hline 2001 & 730405 & 38447.21 & 2222.096 & 21259.41 & 5.2638 & 5.1853793 & 55.2951 \\
\hline 2002 & 814862 & 52873.35 & 2857.108 & 22799.94 & 6.4886 & 5.4324141 & 43.1218 \\
\hline 2003 & 931148 & 73304.81 & 2579.143 & 39254.59 & 7.8725 & 4.7917067 & 53.5498 \\
\hline 2004 & 1185913 & 115306 & 3295.211 & 78589.69 & 9.723 & 4.224487 & 68.1575 \\
\hline 2005 & 1629866 & 180855.7 & 4259.153 & 138173.9 & 11.0964 & 3.2127038 & 76.4001 \\
\hline 2006 & 1930635 & 180678.2 & 7349.257 & 132726.4 & 9.3585 & 2.9188034 & 73.4601 \\
\hline 2007 & 2197852 & 178407.8 & 9251.123 & 126682.8 & 8.1174 & 2.531872 & 71.0074 \\
\hline 2008 & 2829368 & 173984.6 & 9451.563 & 121817.3 & 6.1492 & 2.8577961 & 70.0161 \\
\hline 2009 & 2968036 & 179918.2 & 8621.154 & 123923.6 & 6.0619 & 2.3550002 & 68.8778 \\
\hline 2010 & 3055970 & 198834.6 & 8399.742 & 133537.9 & 6.5064 & 4.0675951 & 67.1603 \\
\hline 2011 & 3301603 & 242245.9 & 7782.642 & 163500.9 & 7.3372 & 5.1853793 & 67.4938 \\
\hline 2012 & 3807648 & 273513.7 & 7983.327 & 182380.6 & 7.1833 & 5.4324141 & 66.6806 \\
2013 & 4350492 & 332044.2 & 8406.935 & 222086.6 & 7.6323 & 4.7917067 & 66.8847 \\
\hline
\end{tabular}

* Includes Visa, Master Card, American Express, and Others.

** Other loans $=$ OLOAN $=$ Consumer bank loans -Real estate loans- Car loans - Equipment finance.

Source: Authors' own calculation using the Saudi Arabian Monetary Agency (SAMA) Annual Report, different issues.

The ratio of CLOAN to TOTALL (Table 1) increased during the stock market boom, reaching its peak at $11 \%$ in 2005. Following the stock market downturn in 2006, the ratio of CLOAN to TOTALL decreased until 2010, and then started to improve as the stock market began to recover. OLOAN constitute about $66 \%$ of CLOAN. The ratio of OLOAN to CLOAN increased during the stock market boom, reaching its peak at $76 \%$ in 2005 , and then started to decrease. The study pays more attention to OLOAN as part of CLOAN because it is expected to be the most effected by stock prices.

As shown in Table 2, the growth of all loans was very high during the stock market booms in 2004 and 2005 , indicating that the demand for loans increases as the stock price index increases. What seems to be the most influenced by the stock market is OLOAN, which is part of CLOAN. During the stock market booms in 2004 and 2005 , the growth rate of OLOAN was $100 \%$ and $75 \%$, respectively. 
Table 2. Growth Rate Of Bank Loans

\begin{tabular}{ccccc}
\hline End Of Period & $\begin{array}{c}\text { Growth Rate Of } \\
\text { Total Bank Loans }\end{array}$ & $\begin{array}{c}\text { Growth Rate Of } \\
\text { Consumer Loans }\end{array}$ & $\begin{array}{c}\text { Growth Rate Of } \\
\text { Others Loans }\end{array}$ & $\begin{array}{c}\text { Growth Rate Of } \\
\text { Credit Card Loans }\end{array}$ \\
\hline 1999 & -2.202 & 36.2079 & 46.98032 & 8.042534 \\
\hline 2000 & 2.8701 & 101.3934 & 85.61039 & -8.7809 \\
\hline 2001 & 9.3322 & 55.3064 & 48.53873 & 2.190914 \\
\hline 2002 & 11.563 & 37.522 & 7.246316 & -9.72889 \\
\hline 2003 & 14.2706 & 38.6423 & 72.16974 & 27.7638 \\
\hline 2004 & 27.3603 & 57.2967 & 100.2051 & 29.25282 \\
\hline 2005 & 37.4355 & 56.8485 & 75.8169 & 72.55208 \\
\hline 2006 & 18.4536 & -0.098 & -3.94255 & 25.87834 \\
\hline 2007 & 13.8409 & -1.257 & -4.55342 & 2.166656 \\
\hline 2008 & 28.7333 & -2.479 & -3.8407 & -8.78594 \\
\hline 2009 & 4.901 & 3.4104 & 1.729112 & -2.56824 \\
\hline 2010 & 2.9627 & 10.5139 & 7.758232 & -7.34665 \\
\hline 2011 & 8.0378 & 21.8328 & 22.43784 & 2.578623 \\
\hline 2012 & 15.3273 & 12.9075 & 11.5471 \\
\hline 2013 & 14.2567 & 21.3995 & 21.77101 \\
\hline
\end{tabular}

\section{Augmented Dick-Fuller Test}

This paper uses the Augmented Dicky-Fuller (ADF) test to examine the presence of unit roots in the variables. The ADF test is an extended version of the original Dicky and Fuller (DF) (1979) test to control for the serial correlation of the error term (Dicky and Fuller, 1981). For cointegration in empirical methodology, variables that are non-stationary in level but stationary after first differencing are required. To test whether the variables are stationary or not, unit root tests are performed. The time series properties of variables are examined with the DF or ADF unit root test. This is used to determine the order of integration of time series. The test is based on estimates of the following regression equations:

For level,

$$
\Delta x_{t}=\propto_{1}+\propto_{2} T+\propto_{3} x_{t-1}+\sum_{i=1}^{p} \propto_{4 i} \Delta x_{t-i}+\varepsilon_{t}
$$

and for first difference,

$$
2_{\Delta} x_{t}=\propto_{1}+\propto_{2} T+\propto_{3} \Delta x_{t-1}+\sum_{i=1}^{p} \propto_{4 i} 2_{\Delta} \mathrm{x}_{\mathrm{t}-\mathrm{i}}+\varepsilon_{t}
$$

where variable $x_{t}$ is the variable tested for unit root, $\Delta$ is the first difference operator, $\propto_{1}$. is the constant term, $T$ is the time trend, and $\mathrm{p}$ is the selected number of lag lengths. The null hypothesis is $\mathrm{H}_{0}: \propto_{3}=0$ and alternative hypothesis $\mathrm{H}_{1}: \propto_{3}<0$. When the absolute value of the calculated t-test is greater than the critical value, from Mackinnon (1991), the null hypothesis of the unit root (non-stationary) is rejected, indicating that the variable is stationary at level and integrated of degree zero [I (0)]. However, when the absolute value of the calculated t-test is smaller than the critical value, the null hypothesis of the unit root (non-stationary) is accepted, indicating that the variable is non-stationary at level form and we have to check for stationarity at the first difference.

\section{Johansen Cointegration Test}

In order to examine the cointegration relationship between the stock market index and M1 and M2, the widely used Johansen $(1988,1991)$ cointegration test, which implements a maximum-likelihood procedure is employed. This is because the time series variables in this paper are non-stationary in level but stationary after first differencing. If a cointegration relationship between bank loans and the stock market price index variables is found, it implies a long-run relationship between the stock market price index and bank loans. This methodology tests for the number of cointegration relationships and estimates the parameters of such cointegrating relationships. The cointegration is applied by using the VAR model. A general unrestricted VAR model can be represented as the 
following equation:

$\mathrm{y}_{\mathrm{t}}=A_{0}+\mathrm{A}_{1} \mathrm{y}_{\mathrm{t}-1}+\cdots+\mathrm{A}_{\mathrm{p}} \mathrm{y}_{\mathrm{t}-\mathrm{p}}+\eta_{\mathrm{t}} \quad \mathrm{t}=1,2, \ldots, \mathrm{T}$

where $y_{t}$ is an ( $\left.\mathrm{nx} 1\right)$ vector of variables, $\alpha$ an ( $\left.\mathrm{n} \times 1\right)$ vector of constant terms, and $\eta_{t}$ an $(\mathrm{n} \times 1)$ vector of usual error term. Equation (3) can be rewritten in the following error correction form:

$\Delta y_{t}=A_{0}+\sum_{i=1}^{p-1} \Gamma_{i} \Delta y_{t-i}+\Pi y_{t-1}+\eta_{t}$

where

$\Pi=\sum_{i=1}^{p} A_{i}-I$ and $\Gamma_{i}=-\sum_{j=i+1}^{p} A_{j}$

If the coefficient matrix $\Pi$ has a reduced rank $\mathrm{r}<\mathrm{k}$, then there must exist $\mathrm{k} x \mathrm{r}$ matrices $\alpha$ and $\beta$ each with rank $r$ such that $\pi=\alpha \beta^{\prime}$ and $\beta y_{t}$ is stationary. Here, $r$ is the number of cointegrating relationships, the elements of $\alpha$ are defined as the adjustment parameters, and each column of $\beta$ is a cointegrating vector. The Johansen-Juselius test uses two test statistics using the VAR model to identify the number of cointegrating vectors, namely, the trace test statistic and the maximum eigenvalue test statistic. The test statistic for the trace test is given by

Trace $=-T \sum_{i=r+1}^{n} \operatorname{In}\left(1-\hat{\lambda}_{i}\right)$

The trace test's null hypothesis is $r=0$ cointegrating vectors against the alternative hypothesis of $n$ cointegrating vectors.

The maximum eigenvalue test is given by

$\lambda_{\max }=-T \operatorname{In}\left(1-\hat{\lambda}_{r+1}\right)$

This test, on the other hand, tests for the null hypothesis of $r$ cointegrating vectors against the alternative hypothesis of $(r+1)$ cointegrating vectors.

\section{Vector Error Correction Model}

Once a cointegration relationship is established between variables, a need arises for the construction of an error correction mechanism to model the dynamic relationship. The aim of the error correction model is to indicate the speed of adjustment from the short-run to the long-run equilibrium. A Vector Error Correction Model (VECM) is a restricted VAR model used with non-stationary series that are cointegrated. When equilibrium conditions are imposed, the VECM describes how the model is adjusting in each time period toward its long-run equilibrium. Because the variables are supposed to be cointegrated, any deviation from the long-run equilibrium will feedback in the short run on changes in the dependent variables in order to move toward the long-run equilibrium. According to Engle and Granger (1987), if two series are co-integrated of order one, that is, $I(1)$, then there must exist a VECM representation in order to govern the joint behavior of the series of the dynamic system. For this study, estimation of VECM as follows:

$$
\begin{aligned}
& \triangle \operatorname{CCLOAN}_{t}=\propto_{1}+\sum_{i=1}^{p} \propto_{2 i} \Delta \operatorname{CCLOAN}_{t-i}+\sum_{i=1}^{n} \propto_{3 i} \Delta \operatorname{SSPI}_{t-i}+\sum_{i=1}^{n} \propto_{4 i} \Delta \pi+\propto_{5 i} e_{t-1}+\delta_{1 \mathrm{t}} \\
& \triangle \text { CLOAN }_{t}=\propto_{1}+\sum_{i=1}^{p} \propto_{2 i} \Delta \operatorname{CLOAN}_{t-i}+\sum_{i=1}^{n} \propto_{3 i} \Delta \operatorname{SSPI}_{t-i}+\sum_{i=1}^{n} \propto_{4 i} \Delta \pi+\propto_{5 i} e_{t-1}+\delta_{1 \mathrm{t}} \\
& \triangle \text { OLOAN }_{t}=\propto_{1}+\sum_{i=1}^{p} \propto_{2 i} \Delta \operatorname{OLOAN}_{t-i}+\sum_{i=1}^{n} \propto_{3 i} \Delta \operatorname{SSPI}_{t-i}+\sum_{i=1}^{n} \propto_{4 i} \Delta \pi+\propto_{5 i} e_{t-1}+\delta_{1 \mathrm{t}} \\
& \triangle \text { TOTALL }_{t}=\propto_{1}+\sum_{i=1}^{p} \propto_{2 i} \Delta \operatorname{TOTALL}_{t-i}+\sum_{i=1}^{n} \propto_{3 i} \Delta \operatorname{SSPI}_{t-i}+\sum_{i=1}^{n} \propto_{4 i} \Delta \pi+\propto_{5 i} e_{t-1}+\delta_{1 \mathrm{t}}
\end{aligned}
$$


$\Delta \operatorname{SSPI}_{t}=\propto_{1}+\sum_{i=1}^{p} \propto_{2 i} \Delta \operatorname{CCLOAN}_{t-i}+\sum_{i=1}^{n} \propto_{3 i} \Delta \operatorname{SSPI}_{t-i}+\sum_{i=1}^{n} \propto_{4 i} \Delta \pi+\propto_{5 i} e_{t-1}+\delta_{2 \mathrm{t}}$

$\Delta \mathrm{SSPI}_{t}=\propto_{1}+\sum_{i=1}^{p} \propto_{2 i} \Delta C L O A N_{t-i}+\sum_{i=1}^{n} \propto_{3 i} \Delta S S P I_{t-i}+\sum_{i=1}^{n} \propto_{4 i} \Delta \pi+\propto_{5 i} e_{t-1}+\delta_{2 \mathrm{t}}$

$\Delta \mathrm{SSPI}_{t}=\propto_{1}+\sum_{i=1}^{p} \propto_{2 i} \Delta O L O A N_{t-i}+\sum_{i=1}^{n} \propto_{3 i} \Delta S S P I_{t-i}+\sum_{i=1}^{n} \propto_{4 i} \Delta \pi+\propto_{5 i} e_{t-1}+\delta_{2 \mathrm{t}}$

$\Delta \mathrm{SSPI}_{t}=\propto_{1}+\sum_{i=1}^{p} \propto_{2 i} \Delta$ TOTAL $_{t-i}+\sum_{i=1}^{n} \propto_{3 i} \Delta S S P I_{t-i}+\sum_{i=1}^{n} \propto_{4 i} \Delta \pi+\propto_{5 i} e_{t-1}+\delta_{2 \mathrm{t}}$

where $e_{t-1}$ is the error correction term lagged one period with coefficient $\alpha_{5}$ measuring the adjustment of model from the short run to the long run and $\delta$ is the white noise. The estimation of these two equations determines the nature of the relationship between SSPI and CCLOAN.

Whether a VAR model in levels or a VECM is a better approach for modeling cointegrated series remains debatable. While the VECM conveniently combines the long-run behavior and short-run interactions of the variables and thus can better reflect the relationship between the variables, the popularity of the VAR model in levels lies in its low computational burden. Moreover, it is still unclear whether the VECM outperforms the VAR model in levels at all forecasting horizons (Naka and Tufte, 1997). In the literature dealing with short-run dynamic interactions, it seems to be normal to estimate the VAR model in levels for cointegrated variables.

In the Granger representation theorem, Granger (1986) states that if two variables are stationary of order (1) and cointegrated, then either the first variable leads to the second variable or vice versa. In this study, the Granger causality test based on VECM is used. This provides an additional channel for long-run causality, which is ignored by the Sims and Granger causality tests. Long-run causality is confirmed using the joint significance of the coefficients of lagged variables. A Chi-squared test is employed to check the joint significance of the coefficients of lagged variables and t-tests are used to check for significance of the error term.

\section{EMPIRICAL RESULTS}

\section{Unit Root Test}

Table 3 presents the Augmented Dicky-Fuller (ADF) test And Phillips-Perron Test Statistics to examine the presence of unit roots in the variables.

Table 3. Augmented Dickey-Fuller And Phillips-Perron Test Statistics

\begin{tabular}{lcc|cc}
\hline & \multicolumn{2}{c|}{ Augmented Dickey-Fuller Test Statistic } & \multicolumn{2}{c}{ Phillips-Perron Test Statistic } \\
\hline Variables & Level With Constant & $\begin{array}{c}\text { First Difference } \\
\text { With Constant }\end{array}$ & Level With Constant & $\begin{array}{c}\text { First Difference } \\
\text { With Constant }\end{array}$ \\
\hline TLOAN & 1.752768 & $-2.891138^{*}$ & 2.301869 & $-3.004322^{*}$ \\
CLOAN & 0.333429 & $-3.093945^{*}$ & 0.982603 & $-5.336309^{* *}$ \\
CCLOAN & -1.601751 & $-2.933945^{*}$ & -0.722393 & $-5.851991^{* *}$ \\
OLOAN & -0.175934 & $-3.026980^{*}$ & 0.404549 & $-6.199411^{* *}$ \\
SSPI & -1.542595 & $-5.421834^{* *}$ & -1.821643 & $-5.445487^{* *}$ \\
\hline
\end{tabular}

Note: * Statistically significant at the $5 \%$ level.

** Statistically significant at the $1 \%$ level.

From the results of Table 3, the author cannot reject the presence of unit root for any of the variables. All variable are not stationary at their levels but stationary at the first difference. Therefore, all variables are integrated of order one, $\mathrm{I} \sim(1)$, for both root tests, the ADF test statistic and Phillips-Perron test statistic.

\section{Johansen Cointegration Test}

Table 4 presents the cointegration test results of SSPI and the following variables: TOTALL, CLOAN, CCLOAN, and OLOAN, respectively. 
Table 4. Johansen Cointegration Test

\begin{tabular}{|c|c|c|c|c|}
\hline \multicolumn{5}{|c|}{ Panel A: Cointegration Test - TOTALL And SSPI With Intercept And No Trend } \\
\hline $\mathrm{R}$ & Trace Statistic & 0.05 Critical Value & Max-Eigen Statistic & 0.05 Critical Value \\
\hline None & 12.04182 & 15.49471 & 9.620138 & 14.26460 \\
\hline At most 1 & 2.421683 & 3.841466 & 2.421683 & 3.841466 \\
\hline \multicolumn{5}{|c|}{ Panel B: Cointegration Test - TOTALL And SSPI With Intercept And Trend } \\
\hline $\mathrm{R}$ & Trace Statistic & 0.05 Critical Value & Max-Eigen Statistic & 0.05 Critical Value \\
\hline None & 22.56034 & 25.87211 & 13.01733 & 19.38704 \\
\hline At most 1 & 9.543006 & 12.51798 & 9.543006 & 12.51798 \\
\hline \multicolumn{5}{|c|}{ Panel C: Cointegration Test - CLOAN And SSPI With Intercept And No Trend } \\
\hline $\mathrm{R}$ & Trace Statistic & 0.05 Critical Value & Max-Eigen Statistic & 0.05 Critical Value \\
\hline None & 13.16515 & 15.49471 & 9.891859 & 14.26460 \\
\hline At most 1 & 3.273291 & 3.841466 & 3.27329 & 3.841466 \\
\hline \multicolumn{5}{|c|}{ Panel D: Cointegration Test - CLOAN And SSPI With Intercept And Trend } \\
\hline $\mathrm{R}$ & Trace Statistic & 0.05 Critical Value & Max-Eigen Statistic & 0.05 Critical Value \\
\hline None & 15.66256 & 25.87211 & 10.02635 & 19.38704 \\
\hline At most 1 & 5.636219 & 12.51798 & 5.636219 & 12.51798 \\
\hline \multicolumn{5}{|c|}{ Panel E: Cointegration Test - CCLOAN And SSPI With Intercept And No Trend } \\
\hline $\mathrm{R}$ & Trace Statistic & 0.05 Critical Value & Max-Eigen Statistic & 0.05 Critical Value \\
\hline None $*$ & 32.41015 & 15.49471 & 31.28170 & 14.26460 \\
\hline At most 1 & 1.128453 & 3.841466 & 1.12845 & 3.841466 \\
\hline \multicolumn{5}{|c|}{ Panel F: Cointegration Test - CCLOAN And SSPI With Intercept And Trend } \\
\hline $\mathrm{R}$ & Trace Statistic & 0.05 Critical Value & Max-Eigen Statistic & 0.05 Critical Value \\
\hline None* & 35.90864 & 25.87211 & 31.80537 & 19.38704 \\
\hline At most 1 & 4.103269 & 12.51798 & 4.103269 & 12.51798 \\
\hline \multicolumn{5}{|c|}{ Panel G: Cointegration Test - OLOAN And SSPI With Intercept And No Trend } \\
\hline $\mathrm{R}$ & Trace Statistic & 0.05 Critical Value & Max-Eigen Statistic & 0.05 Critical Value \\
\hline None & 11.99828 & 15.49471 & 11.09018 & 14.26460 \\
\hline At most 1 & 0.908105 & 3.841466 & 0.908105 & 3.841466 \\
\hline \multicolumn{5}{|c|}{ Panel H: Cointegration Test - OLOAN And SSPI With Intercept And Trend } \\
\hline $\mathrm{R}$ & Trace Statistic & 0.05 Critical Value & Max-Eigen Statistic & 0.05 Critical Value \\
\hline None & 17.35786 & 25.87211 & 11.11730 & 19.38704 \\
\hline At most 1 & 6.240565 & 12.51798 & 6.240565 & 12.51798 \\
\hline
\end{tabular}

The study confirms the long-run relationship between CCLOAN and SSPI. Trace tests as well as Maxeigenvalue tests indicate one cointegration equation at the $5 \%$ significance level. This is true for both with intercept only and with intercept and trend. However, for the rest of variables: TOTALL, CLOAN, and OLOAN, the null hypothesis could not be rejected and the study does not confirm any long-run relationship between SSPI and these variables. Trace tests as well as Max-eigenvalue tests indicate no cointegration equation at the $5 \%$ significance level. This is true for both with intercept only and with intercept and trend.

\section{Vector Error Correction Model Result}

Since CCLOAN and SSPI are co-integrated of order one, that is, $I(1)$, there must exist a VECM representation so as to govern joint behavior of the series of the dynamic system. In VECM specification, short-run as well as long-run adjustments are made. The co-movement between CCLOAN and SSPI suggests the use of VECM to model the dynamic relationship between the two variables. Lag order selection criteria, mainly Akaike information criterion (AIC) and Schwarz information criterion (SC), suggest the choice of four lags. Table 5 represents the VECM estimate results with four lags: 
Table 5. Vector Error Correction Model Results

\begin{tabular}{|c|c|c|}
\hline \multicolumn{3}{|l|}{ Panel A: VECM Result } \\
\hline Error Correction & D(CCLOAN) & D(SSPI) \\
\hline \multirow{3}{*}{ CointEq1 } & -0.102233 & -0.000111 \\
\hline & $(0.02071)$ & $(9.0 \mathrm{E}-05)$ \\
\hline & {$[-4.93675]$} & {$[-1.23153]$} \\
\hline \multirow{3}{*}{$\mathrm{D}\left(C C L O A N_{-1}\right)$} & -0.153893 & -0.000624 \\
\hline & $(0.10299)$ & $(0.00045)$ \\
\hline & {$[-1.49431]$} & {$[-1.39819]$} \\
\hline \multirow{3}{*}{$\mathrm{D}\left(C C L O A N_{-2}\right)$} & -0.251435 & $9.39 \mathrm{E}-05$ \\
\hline & $(0.09948)$ & $(0.00043)$ \\
\hline & {$[-2.52746]$} & {$[0.21771]$} \\
\hline \multirow{3}{*}{$\mathrm{D}\left(C C L O A N_{-3}\right)$} & -0.293705 & -0.000433 \\
\hline & $(0.10543)$ & $(0.00046)$ \\
\hline & {$[-2.78575]$} & {$[-0.94770]$} \\
\hline \multirow{3}{*}{$\mathrm{D}\left(C_{C L O A N}-4\right)$} & 0.498971 & -0.000926 \\
\hline & $(0.10363)$ & $(0.00045)$ \\
\hline & [4.81501] & {$[-2.06155]$} \\
\hline \multirow{3}{*}{$D\left(S S P I_{-1}\right)$} & -97.52073 & 0.152652 \\
\hline & $(32.5424)$ & $(0.14111)$ \\
\hline & {$[-2.99673]$} & {$[1.08177]$} \\
\hline \multirow{3}{*}{$D\left(S S P I_{-2}\right)$} & -112.5161 & 0.254307 \\
\hline & $(33.9769)$ & $(0.14733)$ \\
\hline & {$[-3.31155]$} & {$[1.72606]$} \\
\hline \multirow{3}{*}{$D\left(S S P I_{-3}\right)$} & -65.79750 & -0.200053 \\
\hline & $(37.4983)$ & $(0.16260)$ \\
\hline & {$[-1.75468]$} & {$[-1.23031]$} \\
\hline \multirow{3}{*}{$D\left(S S P I_{-4}\right)$} & -18.93432 & -0.603827 \\
\hline & $(37.3913)$ & $(0.16214)$ \\
\hline & {$[-0.50638]$} & {$[-3.72412]$} \\
\hline \multirow{3}{*}{$\mathbf{C}$} & 150387.0 & 333.4855 \\
\hline & $(43478.4)$ & $(188.535)$ \\
\hline & [3.45889] & {$[1.76883]$} \\
\hline R-squared & 0.682377 & 0.418783 \\
\hline Adj. R-squared & 0.624038 & 0.312029 \\
\hline F-statistic & 11.69677 & 3.922879 \\
\hline \multicolumn{3}{|c|}{ Panel B: VEC Granger Causality/Block Exogeneity Wald Tests } \\
\hline Dependent Var. & $\mathrm{D}(\mathrm{CCLOAN})$ & $\mathrm{D}(\mathrm{SSPI})$ \\
\hline Excluded & $\mathrm{D}(\mathrm{SSPI})$ & $\mathrm{D}(\mathrm{CCLOAN}))$ \\
\hline Chi-sq & 22.86785 & 6.762345 \\
\hline df & 4 & 4 \\
\hline Prob. & 0.0001 & 0.1490 \\
\hline
\end{tabular}

Note: Standard errors are shown in ( ), t-statistics are shown in [ ].

From Table 5 Panel A, the error correction coefficients are negative and significant at the $1 \%$ level, indicating that a deviation from long-run equilibrium value in one period is corrected in the next period by the size of the coefficient. The coefficient of the error term is -0.10 , indicating low speed of adjustment toward long-run equilibrium. This indicates that in case there is a disturbance in the system, only a $10 \%$ correction would take place to the disequilibrium in one quarter. In other words, the rate of convergence to the equilibrium state per quarter is about $10 \%$ of the disequilibrium in CCLOAN. From the VECM estimation results, the relationship between CCLOAN and the lags of SSPI is negative. Therefore, when the stock price increases, CCLOAN decreases, thus contradicting the theory. This can be justified because CCLOAN are influenced mainly by the consumption decision that depends on the wealth effect. That is, when stock prices are booming, people get wealthier and therefore reduce their credit card borrowings. 
From the VECM results, the study confirms not only a long-run relationship between CCLOAN and SSPI but also a short-run relationship between the variables since the computed $\mathrm{F}$ is larger than the critical value.

From Table 5 Panel B showing the VEC Granger Causality/Block Exogeneity Wald Test results, this study confirms that all lags of SSPI are jointly significant at the $1 \%$ level and affect CCLOAN. The result confirms the long-run as well as short-run causality running from SSPI to CCLOAN. In other words, some of the changes in CCLOAN can be explained by SSPI. This result is consistent with the MEH. This is because the predictability of stock prices cannot be enhanced by using bank loan information. An important implication from this result is that the health of the banking sector depends partly on the stock market's stability. Thus, policies to stimulate CCLOAN in an attempt to boost stock market activities may be futile.

\section{VAR Results}

This work needs integration and cointegration tests for the proper specification of the VAR model in order to avoid spurious regression or misspecification problems. In particular, the findings that the variables are nonstationary and non-cointegrated suggest the use of the VAR model at first differences. Because no cointegration exists between SSPI and the other types of bank loans (i.e., TOTALL, CLOAN, and OLOAN), the unrestricted VAR model at first differences is recommended.

For TOTALL and SSPI, the study found the optimal lag selection to be five according to AIC and SC. Table 6, Panel A represents the VAR estimates. The first and second lag variables of SSPI affect TOTALL positively, but the other lag variables affect TOTALL negatively, indicating that in the short run, SSPI has a positive effect on the movement of TOTALL, but the net effect in the long run is not clear.

For CLOAN and SSPI, the study found the optimal lag selection to be four according to AIC and SC. Table 6, Panel B represents the VAR estimates. The equation of D(SSPI) from Table 6, Panel B provides us with a positive and significant relationship between CLOAN and SSPI. Therefore, the sign of the first and second lags of CLOAN is positive and significant, indicating that CLOAN influences SSPI positively.

For OLOAN and SSPI, the study found the optimal lag selection to be four according to AIC and SC. Table 6, Panel C represents the VAR estimates. Most of the lag variables of OLOAN affect SSPI positively. As the other bank loans increase, the demand for stocks increases, and therefore SSPI increases. The behavior of OLOAN is similar to that of CLOAN because the former is part of the latter.

Table 6. Vector Autoregression Estimates

\begin{tabular}{|c|c|c|c|c|c|c|c|c|}
\hline \multicolumn{3}{|c|}{ Panel A: TOTALL And SSPI } & \multicolumn{3}{|c|}{ Panel B: CLOAN And SSPI } & \multicolumn{3}{|c|}{ Panel C: OLOAN And SSPI } \\
\hline & $\mathrm{D}($ TOTALL $)$ & D(SSPI) & & $\mathrm{D}($ CLOAN $)$ & D(SSPI) & & $\mathrm{D}(O L O A N)$ & D(SSPI) \\
\hline \multirow{3}{*}{$\mathrm{D}\left(\right.$ TOTALL $\left.L_{-1}\right)$} & 0.764834 & $-9.36 \mathrm{E}-06$ & & 0.063251 & $6.39 \mathrm{E}-05$ & \multirow{3}{*}{$\mathrm{D}\left(O L O A N_{-1}\right)$} & 0.031171 & $8.48 \mathrm{E}-05$ \\
\hline & $(0.12690)$ & $(1.5 \mathrm{E}-05)$ & $\mathrm{D}\left(C_{L O A N_{-1}}\right)$ & $(0.15157)$ & $(2.5 \mathrm{E}-05)$ & & $(0.15031)$ & $(2.5 \mathrm{E}-05)$ \\
\hline & {$[6.02689]$} & {$[-0.61783]$} & & {$[0.41731]$} & [2.60142] & & {$[0.20738]$} & [3.36617] \\
\hline \multirow{3}{*}{$D\left(T_{O T A L L}\right)$} & -0.135649 & $1.56 \mathrm{E}-05$ & & 0.140112 & $4.94 \mathrm{E}$ & \multirow{3}{*}{$\mathrm{D}\left(O L O A N_{-2}\right)$} & 0.222265 & $5.67 \mathrm{~B}$ \\
\hline & $(0.15880)$ & $(1.9 \mathrm{E}-05)$ & $\mathrm{D}\left(C L O A N_{-2}\right)$ & $(0.14793)$ & $(2.4 \mathrm{E}-05)$ & & $(0.15785)$ & 05) \\
\hline & {$[-0.85422]$} & {$[0.82355]$} & & {$[0.94713]$} & [2.05996] & & {$[1.4$} & 53] \\
\hline \multirow{3}{*}{$\mathrm{D}\left(\right.$ TOTALL $\left._{-3}\right)$} & 0.102013 & $-1.90 \mathrm{E}-05$ & & 0.226834 & $-5.61 \mathrm{E}-06$ & \multirow{3}{*}{$\mathrm{D}\left(\mathrm{OLOAN}_{-3}\right)$} & 0.183420 & $1.20 \mathrm{E}-05$ \\
\hline & $(0.16002)$ & $(1.9 \mathrm{E}-05)$ & $\mathrm{D}\left(C_{L O A N} \mathrm{AN}_{-3}\right)$ & $(0.13946)$ & $(2.3 \mathrm{E}-05)$ & & $(0.14339)$ & $(2.4 \mathrm{E}$ \\
\hline & {$[0.63750]$} & {$[-0.99447]$} & & {$[1.62648]$} & {$[-0.24814]$} & & [1.27917] & {$[0.49851]$} \\
\hline \multirow{3}{*}{$\mathrm{D}\left(\right.$ TOTALL $\left.L_{-4}\right)$} & 0.428716 & $2.90 \mathrm{E}-05$ & & 0.230370 & $-6.42 \mathrm{E}-05$ & \multirow{3}{*}{$\mathrm{D}\left(O L O A N_{-4}\right)$} & 0.161850 & $-8.04 \mathrm{E}-05$ \\
\hline & $(0.15727)$ & $(1.9 \mathrm{E}-05)$ & $\mathrm{D}\left(\mathrm{CLOAN}_{-4}\right)$ & $(0.19106)$ & $(3.1 \mathrm{E}-05)$ & & $(0.18640)$ & $(3.1 \mathrm{E}-05)$ \\
\hline & [2.72604] & [1.54490] & & {$[1.20576]$} & {$[-2.07449]$} & & {$[0.86828]$} & {$[-2.57212]$} \\
\hline \multirow{3}{*}{$\mathrm{D}\left(T_{O T A L L_{-5}}\right)$} & -0.487595 & $-2.38 \mathrm{E}-05$ & & 1691.255 & 0.065813 & \multirow{3}{*}{$D\left(S S P I_{-1}\right)$} & 914.7641 & 0.078623 \\
\hline & $(0.12360)$ & $(1.5 \mathrm{E}-05)$ & $D\left(S S P I_{-1}\right)$ & (790.709) & $(0.12815)$ & & $(720.186)$ & $(0.12074)$ \\
\hline & {$[-3.94486]$} & {$[-1.61517]$} & & [2.13891] & {$[0.51358]$} & & [1.27018] & [0.65118] \\
\hline \multirow{3}{*}{$D\left(S S P I_{-1}\right)$} & 919.8732 & 0.322288 & & 741.7198 & 0.212165 & \multirow{3}{*}{$D\left(S S P I_{-2}\right)$} & 1007.071 & 0.168468 \\
\hline & (1195.47) & $(0.14272)$ & $D\left(S S P I_{-2}\right)$ & (771.698) & $(0.12507)$ & & (721.773) & $(0.12101)$ \\
\hline & {$[0.76947]$} & [2.25814] & & {$[0.96115]$} & [1.69644] & & [1.39527] & \\
\hline \multirow{2}{*}{$D\left(S S P I_{-2}\right)$} & 1686.284 & 0.309539 & $D(S S P I$ & -1157.882 & -0.071139 & \multirow{2}{*}{$D\left(S S P I_{-3}\right)$} & -1065.391 & -0.070253 \\
\hline & (1136.69) & $(0.13571)$ & $D(D S T-3)$ & $(777.260)$ & $(0.12597)$ & & $(728.561)$ & $(0.12214)$ \\
\hline
\end{tabular}




\begin{tabular}{|c|c|c|c|c|c|c|c|c|}
\hline & {$[1.48350]$} & {$[2.28095]$} & & {$[-1.48970]$} & {$[-0.56475]$} & & {$[-1.46232]$} & {$[-0.57516]$} \\
\hline$D\left(S S P I_{-3}\right)$ & $\begin{array}{l}-1724.503 \\
(1219.09) \\
{[-1.41459]}\end{array}$ & $\begin{array}{c}-0.064241 \\
(0.14554) \\
{[-0.44139]}\end{array}$ & $D\left(S S P I_{-4}\right)$ & $\begin{array}{l}-280.8145 \\
(786.489) \\
{[-0.35705]}\end{array}$ & $\begin{array}{l}-0.402217 \\
(0.12746) \\
{[-3.15558]}\end{array}$ & $D\left(S S P I_{-4}\right)$ & $\begin{array}{r}-9.712225 \\
(719.642) \\
{[-0.01350]}\end{array}$ & $\begin{array}{l}-0.424038 \\
(0.12065) \\
{[-3.51464]}\end{array}$ \\
\hline$D\left(S S P I_{-4}\right)$ & $\begin{array}{c}-1881.522 \\
(1158.78) \\
{[-1.62370]}\end{array}$ & $\begin{array}{l}-0.514810 \\
(0.13834) \\
{[-3.72126]}\end{array}$ & $\mathrm{C}$ & $\begin{array}{l}2052867 . \\
(1241396) \\
{[1.65368]}\end{array}$ & $\begin{array}{r}-153.1426 \\
(201.187) \\
{[-0.76120]} \\
\end{array}$ & $\mathrm{C}$ & $\begin{array}{c}1507025 \\
(1003638 \\
{[1.50156]} \\
\end{array}$ & $\begin{array}{l}-173.2970 \\
(168.261) \\
{[-1.02993]}\end{array}$ \\
\hline$D\left(S S P I_{-5}\right)$ & $\begin{array}{r}-745.3583 \\
(1243.30) \\
{[-0.59950]}\end{array}$ & $\begin{array}{c}0.122063 \\
(0.14843) \\
{[0.82234]} \\
\end{array}$ & & & & & & \\
\hline $\mathrm{C}$ & $\begin{array}{l}5568292 \\
(1905874) \\
{[2.92165]}\end{array}$ & $\begin{array}{c}202.2862 \\
(227.535) \\
{[0.88903]}\end{array}$ & & & & & & \\
\hline R-squared & 0.711640 & 0.386917 & & 0.356555 & 0.458817 & & 0.315885 & 0.513241 \\
\hline Adj. R-squared & 0.650287 & 0.256474 & & 0.253604 & 0.372228 & & 0.206427 & 0.435360 \\
\hline F-statistic & 11.59908 & 2.966173 & & 3.463345 & 5.298783 & & 2.885895 & 6.590030 \\
\hline
\end{tabular}

Note: Standard errors are shown in ( ) and t-statistics are shown in [ ]

Table 7 represents VAR Granger Causality/Block Exogeneity Wald Tests. Panel A indicates the causality runs from SSPI to TOTALL at the 5\% significance level, indicating that some of the movement of TOTALL is explained by the change in SSPI. This result is consistent with MEH. This is because the predictability of stock prices cannot be enhanced by using the information on bank loans. An important implication from this result is that the health of the banking sector depends partly on the stock market's stability. Thus, policies to stimulate TOTALL in an attempt to boost stock market activities may be futile. Panel B shows the causality runs from CLOAN to SSPI, indicating that the movement of CLOAN explains the change in SSPI. Some of the movement of SSPI is explained by the change in CLOAN. Panel C represents causality runs from OLOAN to SSPI, indicating that some of the movement of SSPI can be explained by the changes in OLOAN. Thus, policies to stimulate CLOAN in an attempt to boost the stock market activities may be successful.

Table 7. VAR Granger Causality/Block Exogeneity Wald Tests

\begin{tabular}{lcccccc}
\hline & \multicolumn{2}{c}{ Panel A: TOTALL and SSPI } & \multicolumn{2}{c}{ Panel B: CLOAN and SSPI } & \multicolumn{2}{c}{ Panel C: OLOAN and SSPI } \\
\hline Dependent Var. & D(TOTALL) & D(SSPI) & D(CLOAN) & D(SSPI) & D(OLOAN) & D(SSPI) \\
Excluded & D(SSPI) & D(TOTALL) & D(SSPI) & D(CLOAN) & D(SSPI) & D(OLOAN) \\
Chi-sq & 11.20296 & 3.453473 & 7.537974 & 11.22642 & 5.389973 & 18.07202 \\
df & 5 & 5 & 4 & 4 & 4 & 4 \\
Prob. & 0.0475 & 0.6304 & 0.1100 & 0.0241 & 0.2496 & 0.0012 \\
\hline
\end{tabular}

\section{CONCLUSION}

This paper attempted to investigate the direction of causality and the dynamics of the relationship between the stock price index and bank loans in Saudi Arabia. The study uses a cointegration test and error correction model estimation. Cointegration has been confirmed between CCLOAN and SSPI, enabling us to use VECM. For the rest of the variables, the study uses unrestricted VAR at their first differences instead of VECM because there is no cointegration between them.

This paper found a positive relationship between SSPI and bank loans. This positive relationship, supporting the economic theory, is true for all types of loans except CCLOAN, with which the relationship with the lags of SSPI is negative. Therefore, when stock prices increase, there is a decrease in CCLOAN, contradicting the economic theory. This can be justified because CCLOAN are influenced mainly by the consumption decision, which depends on the wealth effect. That is, when there is a boom in stock prices people get wealthier and as a result reduce their CCLOAN. These causality results confirm that TOTALL and CCLOAN are influenced by the movement of SSPI. Since the fluctuations in stock price index cannot be explained by the variability in TOTALL or CCLOAN, the predictability of stock prices cannot be enhanced by using information on bank loans. Thus, policies to stimulate any part of TOTALL with the exception of CLOAN in an attempt to boost stock market activities may be futile. This result is consistent with MEH. Thus, the stock market of Saudi Arabia tends to be efficient. Nevertheless, causality results confirm that CLOAN as well as OLOAN influence the movement of SSPI. As CLOAN and OLOAN increase, the demand for stocks and SSPI increases. Thus, policies to stimulate CLOAN in an 
attempt to boost stock market activities may be successful. However, since TOTALL includes all types of bank loans, there is evidence that TOTALL reacts positively to an increase in stock prices but bank loans do not influence stock prices. The implication of this result supports the MEH of Saudi Arabia's stock market. An important implication from this study is that the health of the banking sector depends crucially on the stock market's stability. Policies to stimulate bank loans in an attempt to boost stock market activities may be futile.

\section{AUTHOR INFORMATION}

Saud Almutair is professor and the Chairman of the Scientific Committee in the Department of Economics, Imam University, Riyadh. he earned his PhD from CSU Colorado, USA in 1991. His main research interest focus on Economics Theory, International Economics and Public Finance. He is the author of Principle of Microeconomics which written in Arabic language. Dr.Almutair is the author of the main following research paper "Dutch Diseases in a Small Open Economy: The Case of Saudi Arabia", "The Demand for Money In Saudi Arabia", "The Effects of The Global Financial Crisis on the Oil Sector In Saudi Arabia", "The Saudi Stock Market Fluctuation; Causes And Effects", "A Cointegration Analysis of Money Supply and Saudi Stock Price Index", "The Dynamics of Relationship between exports and economic growth in Saudi Arabia", and others.

\section{REFERENCES}

Aydemir, O. and Demirhan, E. (2009), "The relationship between stock prices and exchange rates: Evidence from Turkeyl”, International Research Journal of Finance and Economics, 23, 207-15.

Chen Nan-Kuang (2001) “Asset price fluctuations in Taiwan: Evidence from stock and real estate prices 1973 to 1992 ", Journal of Asian Economics, 12, 215-32.

Dickey, D.A. and Fuller, W.A. (1979), "Distribution of the estimators for autoregressive time series with a unit root", Journal of American Statistical Association, 74(366), 427-31.

Dickey, D.A. and Fuller, W.A. (1981), "Likelihood ratio tests for autoregressive time series with a unit root", Econometrica, 49(4), 1057-72.

Enders, W. (1995), Applied Econometric Time Series, John Wiley \& Sons Inc., United States.

Demirguc-Kunt, A. and Levine, R. (1996), "Stock market development and financial intermediaries: Stylized Facts", The World Bank Economic Review, 10(2), 291-321.

Demirguc-Kunt, A. and Maksimovic, V. (1996), "Financial constraints, uses of funds, and firm growth: An international comparison", World Bank Mimeo.

Engle, Robert F. and Clive W. J. Granger (1987), "Co-integration and error correction: Representation, estimation and testing”, Econometrica, 55, 251-76.

Granger, C.W.J. (1986). "Developments in the study of cointegrated economic variables, Oxford Bulletin of Economics and Statistics,48, 213-28.

Ibrahim, H. M. (2006), "Stock prices and bank loan dynamic in developing country: The case of Malaysia", Journal of Applied Economics, 1, 71-89.

Johansen, S. (1988), "Statistical analysis of cointegration vectors", Journal of Economic Dynamics and Control, 12(2-3), 231-54.

Johansen, S. (1991), "Estimation and hypothesis testing of cointegration vectors in Gaussian vector autoregressive models", Econometrica, 59(6), 1551-80.

Karim, B.A., Lih, L.S., and Karim, Z.A. (2012), "Bank loans and stock prices: An empirical evidence”, Aceh International Journal of Social Sciences, 1(2): 48-52 August ISSN: 2088-9976.

Kim, S.B. and Moreno, R. (1994), "Stock prices and bank lending behavior in Japan”, Economic Review, 1, 31-42.

Levine, R. and Zervos, S. (1998), "Stock market, banks, and economic growth", The American Economic Review, 88(3), 537-58.

MacKinnon, James G. (1991), "Critical values for cointegration tests”, in R. F. Engle and C. W. J. Granger, eds., Long-run Economic Relationships: Readings in Cointegration, Oxford, Oxford University Press.

Naka, Atsuyuki and David R. Tufte (1997), "Examining impulse response functions in cointegrated systems", Applied Economics, 29, 1593-1603.

Omar, M.A., Rahman, A.R.A., Yusof, R.M. Majid, M.S.A. and Rasid, M.E.S.M. (2006), "Efficiency of commercial banks in Malaysia", Asian Academic of Management Journal of Accounting and Finance, 2(2), 19-42.

Ooi, S. K. (2008), "The monetary transmission mechanism in Malaysia: Current developments and issues”, Bank for International Settlements Working Paper No 35.

Saudi Arabian Monetary Agency (SAMA), Annual Report, different Issues.

Saudi Arabian Monetary Agency (SAMA), Quarterly Statistical Bulletin, different Issues.

Yartey, C. A. (2008), “The determinants of stock market development in emerging economies: Is South Africa different?", IMF Working Paper, WP/08/32. 


\section{NOTES}

